\title{
Family Support for Increasing Exclusive Breastfeeding
}

\author{
Nur Masruroh $^{1 *}$; Nine Zainiyatul Istianah ${ }^{2}$ \\ ${ }^{1 *)}$ Universitas Nahdlatul Ulama Surabaya \\ 2 Dinas Kesehatan Sampang Madura
}

\section{ARTICLE INFO}

\section{Article history:}

Received May 06, 2019

Revised May 16, 2019

Accepted May 17, 2019

\section{Keyword:}

Family Support

Exclusive Breastfeeding

*) corresponding author

Midwifery Study Program, Nahdlatul Ulama University, Surabaya, 60231, Indonesia

Email: masruroh@unusa.ac.id

DOI:https://doi.org/10.30604/jika.v4i1.194

\begin{abstract}
A B S T R A C T
Nursing mothers in the process of providing Exclusive Milk need support from the closest people such as family members, friends, relatives, colleagues and from the community. The purpose of this study is to determine the effect of the level of family support for exclusive breastfeeding. This type of research is analytic with a case control approach, a sample of 170 respondents of breastfeeding mothers who have babies aged> 6 months were taken using a cluster random sampling technique. The results showed that in the case group as many as 85 nursing mothers most $(57.1 \%)$ received good family support and almost half $(33.3 \%)$ received less support from the family. Then in the control group as many as 85 breastfeeding mothers, almost half (42.9\%) received good family support and most (66.7\%) lacked support from the family. Analysis using the chi square test results that $p=$ 0.004 which means that $\mathrm{HO}$ is rejected, which means family support can increase exclusive breastfeeding. Families and communities are expected to provide support for mothers to exclusively breastfeed.
\end{abstract}

This is an open access article under the CC-BY-SA license.

\section{INTRODUCTION}

Exclusive breastfeeding is the fulfillment of the baby's nutritional needs by providing breast milk for 6 months without any additional supplements. This is according to the WHO that Exclusive Breastfeeding is only giving ASI without providing food and other drinks for babies from birth to 6 months of age (Ministry of Health, 2012). Giving breast milk continues until the age of 2 years. Giving breast milk for babies has many benefits and advantages, including reducing the risk of digestive and respiratory infections (Henry, Nicolau, Americo, \& Lorena B Ximenes, 2010). In addition, breast milk can also increase IQ and EQ of children (Mannion, 2012).

Data from UNICEF in 2012 showed that only $39 \%$ of infants under the age of 6 months were exclusively breastfed throughout the 
world, then in 2015 increased slightly to $40 \%$. In Indonesia alone, according to the Riskesdas report in 2018, the coverage of exclusive breastfeeding has only reached $74 \%$ of the $80 \%$ target. One reason for not achieving the coverage target is lack of family support. This is related to the socialcultural influence in Maysrakat which provides complementary food to infants before the age of 6 months for various reasons such as lack of breast milk, so that the babies get fat fast and so on (Mannion, 2012)

To be able to provide exclusive breastfeeding optimally, the mother needs to get support from the closest people such as her husband, family members, friends and the wider community. Family support is the external factor that has the greatest influence on the success of exclusive breastfeeding because it has an impact on increasing the mother's confidence in the breastfeeding process (Henry et al., 2010).

\section{METHOD}

The design of the study uses a type of analytic research with a case control method using a retrospective approach. This study aims to determine the influence of family support for exclusive breastfeeding in Ketapang Village, Laok Sampang Madura. The population in this study were all breastfeeding mothers who had babies> 6 months during December 2017 - February 2018 as many as 242 people. A sample of 170 people divided into case groups was 85 mothers who exclusively gave ASI and 85 control mothers were mothers who did not exclusively breastfeed their babies, who were taken using the cluster random sampling method. Data collection by giving questionnaires to be filled for family support variables consists of 15 questions, namely informational support, including family knowledge about ASI, information sources about ASI, solving problems about breastfeeding, providing adequate nutrition for breastfeeding, family assistance in breastfeeding, convincing mothers to give exclusive breastfeeding for her baby. While for the exclusive questionnaire breastfeeding variables 20 questions about the notion of exclusive breastfeeding, the benefits of breastfeeding, the function of breast milk, early feeding (PMT).

\section{RESULTS AND DISCUSSION}

\section{Family support}

Table 1

Family support for nursing mothers

\begin{tabular}{lcccc}
\hline \multirow{2}{*}{$\begin{array}{l}\text { Level of } \\
\text { family } \\
\text { support }\end{array}$} & \multicolumn{3}{c}{$\begin{array}{c}\text { Breastfeeding mothers } \\
\text { breastfeeding } \\
\text { (case) }\end{array}$} & $\begin{array}{c}\text { No Exclusive } \\
\text { Breastfeeding } \\
\text { (control) }\end{array}$ \\
\cline { 2 - 5 } Good & $\mathbf{N}$ & $\%$ & $\mathbf{N}$ & $\%$ \\
\hline Less & 68 & 80 & 51 & 60 \\
\hline \multicolumn{1}{c}{ Total } & 17 & 20 & 34 & 40 \\
\hline \multicolumn{1}{c}{} & 85 & 100 & 85 & 100 \\
\hline
\end{tabular}

Table 1 shows that almost all mothers who give exclusive breastfeeding have good support $(80 \%)$. Likewise, the majority of mothers who did not give exclusive breastfeeding $(60 \%)$ had good support. Family support is very important for the breastfeeding process, because mothers who get love, help and friendship from the closest family can increase milk production and increase the closeness between mother and baby (Fikawati \& Syafiq, 2009). Family support is a process that occurs continuously throughout the lifetime of a person. Family support focuses on the interactions that take place in various social relationships as experienced by individuals. Family support is the attitude, action and family acceptance of an action taken by family members who in this study are given exclusive ASI to their babies. Family members view that supportive people are always ready to provide help and assistance if needed (P Simbolon, 2011). Support or support from the closest person plays an important role in the success or 
failure of the breastfeeding process. The greater the support obtained, the greater the ability to survive to continue breastfeeding. Husband's and family's support is very influential, a mother who lacks support from her husband or other family members can easily be influenced to give formula milk (Fikawati \& Syafiq, 2009).

\section{Exclusive Breastfeeding}

Table 2

Exclusive breastfeeding

\begin{tabular}{lcc}
\hline Breastfeeding & Frequency & Percentage \\
\hline Exclusive & 85 & 50 \\
\hline $\begin{array}{l}\text { Do not } \\
\text { exclusive }\end{array}$ & 85 & 50 \\
\hline Total & 170 & 100 \\
\hline
\end{tabular}

Based on table 2 it is known that half $(50 \%)$ of respondents give exclusive breastfeeding for 6 months for their babies.

Exclusive breastfeeding is very necessary for babies because all breast milk needs can be fulfilled by breastfeeding in the first 6 months of life, then breastfeeding for up to 2 years can have a positive impact on children (Ministry of Health, 2012)

Breast milk has been shown to reduce the risk of digestive and respiratory infections. Breast milk can also reduce and prevent noninfectious diseases such as allergies, obesity, malnutrition, asthma and eczema. Related to all of these things, an understanding of the mother and family is needed about the importance of breast milk for babies (Badriul Hegar, 2012).

The impact of complementary breastfeeding, given early can disrupt the continuity of the lactation process and the baby will be difficult to suckle. Besides that, because the imperfect kidney function can aggravate the work process of the organ (Henry et al., 2010) (Mannion, 2012).

\section{Family support increases exclusive breastfeeding}

Table 3

Family support increases exclusive breastfeeding

\begin{tabular}{|c|c|c|c|c|c|c|c|c|}
\hline \multirow{3}{*}{$\begin{array}{c}\text { Supporting } \\
\text { Family }\end{array}$} & \multicolumn{4}{|c|}{ Giving Breastfeeding } & \multirow{2}{*}{\multicolumn{2}{|c|}{ Total }} & \multirow{3}{*}{$P$ value } & \multirow{3}{*}{ OR } \\
\hline & \multicolumn{2}{|c|}{ Case } & \multicolumn{2}{|c|}{ Control } & & & & \\
\hline & $\mathrm{n}$ & $\%$ & $\mathbf{n}$ & $\%$ & $\mathbf{n}$ & $\%$ & & \\
\hline Good & 68 & 57,1 & 51 & 33,3 & 119 & 70 & \multirow{2}{*}{0,004} & \multirow{2}{*}{2,8} \\
\hline Less & 17 & 42,9 & 54 & 66,7 & 51 & 30 & & \\
\hline
\end{tabular}

Table 3 show that in the case group 68 respondents $(57.1 \%)$ received good family support to give exclusive breastfeeding to their babies, while in the control group respondents who received support were 51 (42.9\%).

The results of statistical tests using chi square showed that family support was shown to increase exclusive breastfeeding in nursing mothers. In calculating the odds ratio through SPSS, the results of 2.8 showed that mothers who received family support had 2.8 times the chance to give exclusive breastfeeding for their babies.

In line with this, research concludes that the support of the closest people in this case is that husbands and families play an important role in increasing the motivation of mothers to provide exclusive breastfeeding for their babies (Simbolon, 2011) (Wahyuningsih \& Machmudah, 2013). 


\section{CONCLUSIONS AND RECOMMENDATION}

Almost all mothers who give exclusive breastfeeding get good family support compared to mothers who do not provide exclusive breastfeeding. Family support influences the provision of exclusive breastfeeding

Suggestions that can be given is the need for education through community service activities, especially for nursing mothers who focus on exclusive breastfeeding. Develop further research on factors that influence family support and factor factors regarding breastfeeding. The limitation of this study is because the implementation of the research coincided with the rainy season so that it was difficult to reach the research location.

\section{REFERENCES}

Badriul Hegar. (2012). Mengapa Ibu Harus Menyusui? Kompas. Retrieved from http://www.idai.or.id/artikel/seputarkesehatan-anak/mengapa-ibu-harusmenyusui-2

Fikawati, \& Syafiq. (2009). Penyebab Keberhasilan dan Kegagalan Praktik Pemberian ASI Eksklusif. Jurnal Kesehatan Masyarakat Nasional, 4(3), 120-131. https://doi.org/10.21109/kesmas.v4i3.1 $\underline{84}$

Henry, B. A., Nicolau, A. I., Americo, C. F., \& Lorena B Ximenes. (2010). Socio
Cultural Factors Influencing Breastfeeding Practice Among Low Income Women in Fortaleza Ceara Brazil: Leiniger's Sunrise Model Perpective. Enfemeria Global, 19. Retrieved from http://scielo.isciii.es/pdf/eg/n19/en_cli nica4.pdf

Kemenkes RI. (2012). Peraturan Pemerintah no 33 tahun 2012 Tentang Pemberian Air Susu Eksklusif. Jakarta: Kemenkes RI. Retrieved from http://hukor.kemkes.go.id/uploads/pro duk_hukum/PP\%20No.\%2033\%20ttg \%20Pemberian\%20ASI\%20Eksklusif. pdf

Mannion. (2012). Maternal Perception of Partner Support During Breasfeeding. International Breastfeeding Journal, 8(4). $\quad$ https://doi.org/10.1186/17464358-8-4

Simbolon, P. (2011). Pengaruh Dukungan Keluarga Terhadap Pemberian ASI Eksklusif di Wilayah Kerja Puskesmas Gurilla Pematangsiantar. Sumatera Utara: Universitas Sumatera Utara. Retrieved from http://repository.usu.ac.id/handle/1234 56789/31289

Wahyuningsih, \& Machmudah. (2013). Dukungan Suami Dalam Pemberian ASI Eksklusif. Jurnal Keperawatan Maternitas. 1 (2), 93-101. Retrieved from

https://jurnal.unimus.ac.id/index.php/J KMat/article/download/995/1044 